\title{
Moderasi GCG dan Leverage terhadap Pengaruh Ukuran Perusahaan pada Tax
}

Avoidance

\author{
Dewa Ayu Intan Sri Devi ${ }^{1}$ \\ Fakultas Ekonomi dan Bisnis \\ Universitas Udayana, Indonesia
}

\author{
A.A. Ngurah Bagus Dwirandra2 \\ Fakultas Ekonomi dan Bisnis \\ Universitas Udayana, Indonesia
}

\begin{abstract}
Surel : intansrd@gmail.com
ABSTRAK

Ukuran perusahaan berpengaruh positif pada Tax Avoidance namun diduga tak senantiasa linear diduga karena adanya faktor kontijensi, dua diantaranya adalah GCG dan Leverage. Penelitian ini bertujuan untuk mengetahui peran GCG dan Leverage terhadap pengaruh Ukuran Perusahaan pada Tax Avoidance dan memeroleh bukti empiris pengaruh ukuran perusahaan pada tax avoidance dengan GCG dan leverage sebagai variabel pemoderasi.Penelitian ini dilakukan pada perusahaan sektor pertambangan dan jasa keuangan yang terdaftar di Bursa Efek Indonesia periode tahun 2014-2018 sebanyak 40 amatan dengan menggunakan teknis analisis data yaitu uji moderated regression analysis (MRA).Hasil penelitian menemukan bahwa ukuran perusahaan berpengaruh positif pada tax avoidance. GCG dapat memperlemah pengaruh ukuran perusahaan pada tax avoidance. Leverage dapat memperkuat pengaruh ukuran perusahaan pada tax avoidance.
\end{abstract}

Kata Kunci: Tax Avoidance; Ukuran Perusahaan; GCG; Leverage.

\section{GCG Moderation and Leverage on The Effect of Company Size on Tax Avoidance}

\begin{abstract}
The size of the company has a positive effect on Tax Avoidance but it is suspected that it is not always linear due to the presence of contingency factors, two of which are GCG and Leverage. This study aims to examine the effect of company size on tax avoidance with corporate governance and leverage as a moderator. This research was conducted on mining and financial services companies listed on the Indonesia Stock Exchange for the period 2014-2018 there were 40 observations using data analysis techniques, namely the moderated regression analysis (MRA) test. The results of the study found that company size had a positive effect on tax avoidance. GCG can weaken the influence of company size on tax avoidance. Leverage can strengthen the effect of company size on tax avoidance.
\end{abstract}

Keywords: Tax Avoidance; Size of Firm; GCG; Leverage.

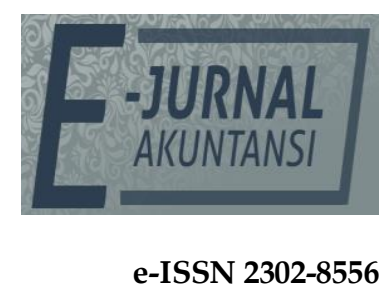

Vol. 30 No. 10

Denpasar, Oktober 2020

Hal. 2578-2590

DOI:

10.24843/EJA.2020.v30.i10.p11

PENGUTIPAN:

Devi, D. A. I. S. \&

Dwirandra, A. A. N. B.

(2020). Moderasi GCG dan Leverage terhadap Pengaruh

Ukuran Perusahaan pada

Tax Avoidance. E-Jurnal Akuntansi, 30(10), 2578-2590

RIWAYAT ARTIKEL: Artikel Masuk: 15 Juni 2020 Artikel Diterima: 28 Juli 2020

Artikel dapat diakses : https://ojs.unud.ac.id/index.php/Akuntansi/index 


\section{PENDAHULUAN}

Pajak merupakan unsur penting dalam menopang penerimaan negara. . Indonesia mendapat pendapatan terbesar di antara pendapatan lainnya, yaitu melalui pendapatan pemungutan pajak yang menyumbang rata-rata lebih dari $70 \%$ dari keseluruhan pendapatan negara dalam berbagai fungsi kenegaraan (Michel Salim, 2012).

Sadarnya akan pentingnya penerimaan atas pajak, maka pemerintah Indonesia melakukan berbagai upaya untuk meningkatkan persentase kenaikkan pendapatan atas pajak di Indonesia. Namun, dalam praktiknya masih banyak ditemukan kendala-kendala yang terjadi sehingga menyebabkan realisasi anggaran atas pajak tidak sesuai dengan target yang seharusnya dicapai per tahun tersebut oleh Indonesia. Adapun target dan realisasi penerimaan atas pajak tahun 2014-2018 dapat dilihat pada Tabel 1, berikut.

Tabel 1. Target dan Realisasi Penerimaan Pajak Tahun 2014-2018

\begin{tabular}{cccc}
\hline Tahun & $\begin{array}{c}\text { Target Penerimaan Pajak } \\
\text { (Triliun) }\end{array}$ & $\begin{array}{c}\text { Realisasi Penerimaan } \\
\text { Pajak (Triliun) }\end{array}$ & Persentase \\
\hline 2014 & $1.072,38$ & 985,13 & $91,86 \%$ \\
2015 & $1.294,25$ & $1.060,86$ & $81.97 \%$ \\
2016 & $1.355,20$ & $1.105,97$ & $81.61 \%$ \\
2017 & $1.283,62$ & $1.151,03$ & $89,67 \%$ \\
2018 & $1.424,00$ & $1.315,51$ & $92,24 \%$ \\
\hline
\end{tabular}

Sumber: www.pajak.go.id, 2019

Tabel 1, menunjukan bahwa persentase realisasi penerimaan pajak terhadap target penerimaan pajak dari tahun 2014 sampai dengan tahun 2018 berfluktuatif. Adanya penurunan penerimaan pajak di tahun 2016 menyebabkan terjadinya penurunan target pajak di tahun selanjutnya yaitu pada tahun 2017. Namun, meskipun telah diturunkannya target penerimaan pada tahun 2017, realisasi penerimaan pajaknya masih tetap saja tidak tercapai. Hal ini menjadi pertanyaan besar faktor apa saja yang memengaruhi mengapa penerimaan pajak belum juga. Namun, meskipun telah diturunkannya target penerimaan pada tahun 2017, realisasi penerimaan pajaknya masih tetap saja tidak tercapai. Hal ini menjadi pertanyaan besar faktor apa saja yang memengaruhi mengapa penerimaan pajak belum juga mencapai target dari tahun ke tahun. Tentunya hal ini tidak dapat dibiarkan begitu saja, terdapat beberapa faktor yang menyebabkan wajib pajak perseorangan maupun badan melakukan kecurangan salah satunya yaitu dari dilakukannya penghindaran pajak (tax avoidance).

Tax Avoidance merupakan salah satu bagian dari tax planning dimana kegiatannya dilegalkan dalam Peraturan Perundang-Undangan dimana metode dan teknik yang digunakan cenderung memanfaatkan kelemahan-kelemahan yang terdapat dalam ketentuan perpajakan (Pohan \& Anwar, 2016). Sektor Pertambangan dan Sektor Jasa Keuangan merupakan dua sektor andalan pemerintah Indoenesia untuk berkontribusi besar pada pendapatan ekonomi Indonesia. Menurut data dari Badan Pusat Statistik, selama 2014-2018 industri pertambangan batu bara dan lignit rata-rata menyumbang 2,3\% terhadap produk domestik bruto (PDB) per tahunnya atau ekuivalen dengan Rp 235 triliun. Begitupula pada sektor jasa keuangan, kontribusi sektor jasa keuangan terhadap 
perekonomian nasional terus mengalami peningkatan. Data peningkatan PDB sektor industri jasa keuangan dapat dilihat pada Table 2, sebagai berikut

Tabel 2. PDB Industri Jasa Keuangan

\begin{tabular}{cccc}
\hline PDB Lapangan Usaha & \multicolumn{3}{c}{ Laju Pertumbuhan PDB } \\
& 2014 & 2015 & 2016 \\
\hline Jasa Keuangan dan Asuransi & $4.68 \%$ & $8.58 \%$ & $8.93 \%$ \\
\hline
\end{tabular}

Sumber: bps.go.id, 2017

Berdasarkan Table 2, terlihat bahwa laju pertumbuhan PDB sektor jasa keuangan dari tahun 2014-2016 terus mengalami peningkatan. Data Badan Pusat Statistik (BPS) menunjukkan, per Februari 2017 sektor jasa keuangan dan asuransi tumbuh dapat tumbuh hingga $4.68 \%$ pada tahun $2014,8.58 \%$ pada tahun 2015 , dan $8.93 \%$ di tahun 2016, cukup tinggi bila dibandingkan sektor lainnya. Secara umum sektor jasa keuangan dan asuransi berkontribusi 4,20 persen pada 2016 atau naik kontribusinya dibanding tahun lalu sebesar 4,03 persen di 2015 dan 2014 sebesar 3,86 persen. Di balik besarnya nilai PDB yang dihasilkan industri pertambangan dan sektor jasa keuangan, namun realitanya pajak yang disetor masihlah sangat minim. Data dari Kementerian Keuangan menunjukkan tax ratio yang dikontribusikan dari sektor pertambangan mineral dan batu bara (minerba) pada 2016 hanya sebesar 3,9\%, sementara tax ratio nasional pada 2016 sebesar 10,4\%. Fenomena penghindaran pajak yang terjadi dapat pula dilihat dalam perusahaan pertambangan dan jasa keuangan dimana pada tahun 2017 terdapat beebrapa perusahaan yang memiliki nilai CETR kurang dari 0.25 atau nilai tariff pembayar pajaknya dibawah tarif pajak yang seharusnya yaitu 25\% Perusahaan pertambangan dan industri jasa keuangan yang memiliki nilai CETR kurang dari 0.25 pada tahun 2017 dapat dilihat pada Tabel 3, dan Tabel 4, berikut.

Tabel 3. CETR Perusahaan Pertambangan Tahun 2017

\begin{tabular}{lrrr}
\hline \multicolumn{1}{c}{ Perusahaan } & Cash Tax Paid & Pre-Tax Income & $\begin{array}{c}\text { Cash } \\
\text { Effective } \\
\text { Tax Rate }\end{array}$ \\
\hline Tambang Batubara Bukit Asam & & & \\
(Persero) Tbk. & $1,120,852$ & $6,101,629$ & 0.184 \\
Petrosa Tbk. & $16,826,616$ & $146,237,112$ & 0.115 \\
Toba Bara Sejahtera Tbk. & $178,814,808,924$ & $815,528,728,836$ & 0.219 \\
Radiant Utama Interinsco Tbk. & $5,628,933,698$ & $38,913,911,728$ & 0.145 \\
Surya Eka Perkasa Tbk. & $14,291,988,420$ & $57,612,463,560$ & 0.248 \\
Cita Mineral Investindo Tbk. & $6,718,101,426$ & $46,827,759,377$ & 0.143 \\
Baramulti Suksessarana Tbk. & $24,731,654$ & $111,688,566$ & 0.221 \\
Darma Henwa Tbk. & $1,695,145$ & $10,827,703$ & 0.157 \\
Harum Energy Tbk. & $11,720,504$ & $73,030,968$ & 0.160 \\
\hline
\end{tabular}

Sumber: Data Penelitian, 2019

Penelitian ini menggunakan agency theory yang mengasumsikan bahwa setiap manusia memiliki sifat egois. Teori keagenan juga mengimplikasikan adanya asimetri informasi antara manajer sebagai agen dan dan pemilik sebagai prinsipal. Manajemen sebagai pengelola perusahaan lebih banyak mengetahui informasi internal sehingga terdapat kesenjangan atau gap akan luasnya informasi yang dimiliki oleh manajemen dengan pemilik. Oleh karena itu sebuah keputusan 
tidak akan pernah memuaskan pihak agen dan prinsipal secara bersama-sama dan kedua belah pihak tidak akan benar-benar setuju untuk melakukan tindakan tersebut bila tidak ada kontrak yang mengikatnya. Maka dalam rangka menjembatani agency problem ini timbul perilaku aggresive tax avoidance dalam rangka mengoptimalkan kedua kepentingan tersebut.

Tabel 4. CETR Perusahaan Jasa Keuangan Tahun 2017

\begin{tabular}{lrrr}
\hline \multicolumn{1}{c}{ Perusahaan } & Cash Tax Paid & Pre-Tax Income & $\begin{array}{c}\text { Cash } \\
\text { Effective } \\
\text { Tax Rate }\end{array}$ \\
\hline Tambang Batubara Bukit & & & \\
Asam (Persero) Tbk. & $1,120,852$ & $6,101,629$ & 0.184 \\
Petrosa Tbk. & $16,826,616$ & $146,237,112$ & 0.115 \\
Toba Bara Sejahtera Tbk. & $178,814,808,924$ & $815,528,728,836$ & 0.219 \\
Radiant Utama Interinsco & & & \\
Tbk. & $5,628,933,698$ & $38,913,911,728$ & 0.145 \\
Surya Eka Perkasa Tbk. & $14,291,988,420$ & $57,612,463,560$ & 0.248 \\
Cita Mineral Investindo Tbk. & $6,718,101,426$ & $46,827,759,377$ & 0.143 \\
Baramulti Suksessarana Tbk. & $24,731,654$ & $111,688,566$ & 0.221 \\
Darma Henwa Tbk. & $1,695,145$ & $10,827,703$ & 0.157 \\
Harum Energy Tbk. & $11,720,504$ & $73,030,968$ & 0.160 \\
\hline
\end{tabular}

Sumber: Data Penelitian, 2019

Salah satu faktor yang dapat mempengaruhi praktik tax avoidance adalah ukuran perusahaan. Ukuran perusahaan dapat diukur salah satunya dengan jumlah aset yang dimiliki. Perusahaan yang memiliki aset besar akan cenderung menghasilkan laba yang besar pula dan berakibatkan pada beban pajak yang harus dibayar juga besar. Semakin besar perusahaan maka transaksi keuangan yang dihadapi pun semakin kompleks. Hal ini mendorong perusahaan semakin besar untuk melakukan praktik tax avoidance pada setiap transaksi dengan cara memanfaatkan celah-celah atau kelemahan yang ada pada peraturan perundangundangan.

Telah banyak dilakukan penelitian mengenai pengaruh ukuran perusahaan pada tax avoidance namun hasil yang diperoleh tidak konsisten. Penelitian mengenai ukuran perusahaan dari Praditasari \& Setiawan (2017) menemukan bahwa ukuran perusahaan berpengaruh negatif pada tax avoidance. Palupi (2018) menyatakan bahwa ukuran perusahaan berpengaruh pada tax avoidance. Berbeda dengan penelitian dari Putra \& Merkusiwati (2016), Rachmithasari (2015), dan Tandean (2016) menyatakan bahwa ukuran perusahaan tidak berpengaruh signifikan pada tax avoidance, dan penelitian dari Janrosl (2019) mengatakan bahwa ukuran perusahaan berpengaruh signifikan terhadap tax avoidance. Penelitian dari Dewinta \& Setiawan (2016) serta Putri \& Putra (2017) menunjukkan bahwa ukuran perusahaan berpengaruh positif dan signifikan pada tax avoidance, sedangkan menurut hasil penelitian Merslythalia \& Lasmana (2017) serta Annisa et al., (2017) ukuran perusahaan tidak berpengaruh pada tax avoidance.

Berdasarkan paparan penelitian sebelumnya pengaruh ukuran perusahaan pada tax avoidance ditemukan hasil yang variatif/tidak konsisten atau masih kontroversi yang diduga karena adanya faktor lain yang mempengaruhi hubungan antara variabel bebas dengan variabel terikat yang mana. Salah satu cara untuk merekonsliasi hasil yang tidak konsisten tersebut 
dapat dilakukan dengan meneliti berbagai faktor kondisional yang bertindak sebagai variabel moderasi dengan pendekatan kontijensi. Penelitian ini menggunakan GCG dan Leverage sebagai variabel pemoderasi. GCG dipilih sebagai variabel pemoderasi karena pada dasarnya GCG memiliki 5 prinsip dasar yakni transparansi, akuntabilitas, responsibility (pertanggungjawaban), independency (kemandirian), dan fairness (kesetaraan dan kewajaran) yang mana ketika kelima prinsip tersebut dilaksanakan dengan optimal maka perusahaan tersebut bisa dikatakan memiliki tata kelola perusahaan yang baik termasuk salah satunya dalam hal memenuhi kewajiban pajaknya. Penelitian yang dilakukan Irawan \& Farahmita, (2012) menunjukkan bahwa implementasi corporate governance memiliki pengaruh positif yang signifikan terhadap pembayaran pajak perusahaan.

Leverage (struktur utang) merupakan rasio yang menunjukkan besarnya utang yang dimiliki oleh perusahaan untuk membiayai aktivitas operasinya. Penambahan jumlah utang akan mengakibatkan munculnya beban bunga yang harus dibayar oleh perusahaan. Komponen beban bunga akan mengurangi laba sebelum kena pajak perusahaan, sehingga beban pajak yang harus dibayar perusahaan akan menjadi berkurang (Mulyani, 2013). Penelitian terkait leverage pernah diteliti sebelumnya oleh Rachmithasari (2015) yang menemukan bahwa leverage berpengaruh positif pada tax avoidance. Hasil penelitian Rachmithasari sebanding dengan hasil dari Nugrahitha \& Suprasto (2018) serta Praditasari \& Setiawan (2017) dimana menyatakan bahwa leverage berpengaruh positif pada tax avoidance.

Alasan peneliti menggunakan perusahaan pertambangan dan jasa keuangan dalam penelitian ini karena kedua sektor tersebut merupakan sektor primer yang dapat meningkatkan pendapatan nasional, namun fakta lapangan menyatakan bahwa kedua sektor tersebut terlibat kasus tax avoidance.

Kerangka konseptual dari penelitian akan ditambilkan pada Gambar 1.

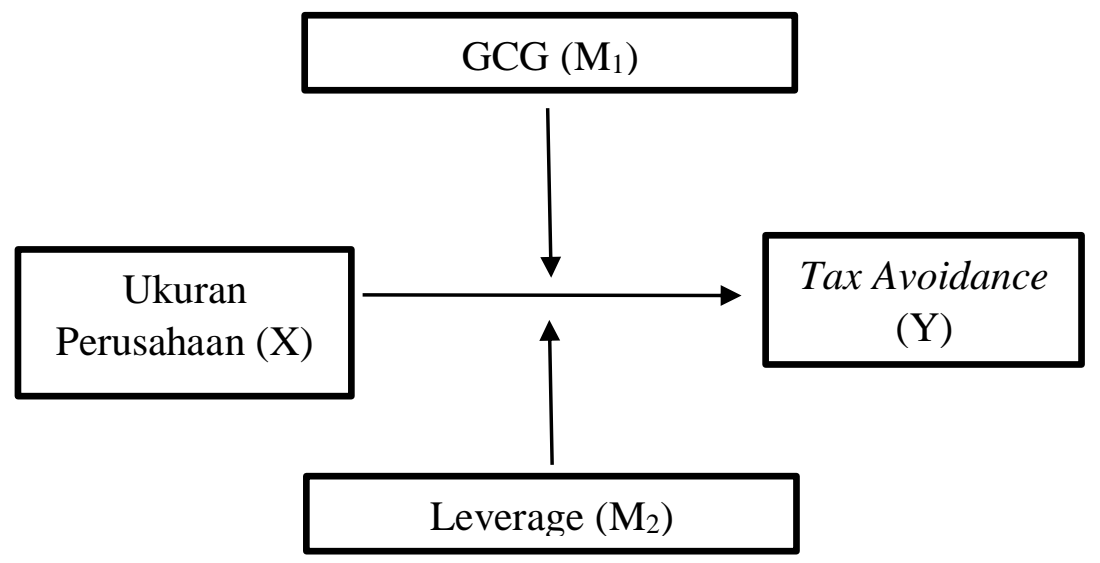

Sumber: Data Penelitian, 2019

Gambar 1. Kerangka Konseptual

Berdasarkan teori biaya politik menyatakan bahwa, semakin besar biaya politik perusahaan, maka semakin mungkin manajer perusahan untuk memilih metode akuntansi yang menangguhkan laba periode sekarang ke periode mendatang. Perusahaan yang masuk dalam kelompok perusahaan besar akan 
lebih bisa dalam menghasilkan laba dan stabil dibandingkan dengan perusahaan yang berukuran kecil. Keuntungan tinggi yang diperoleh akan menyebabkan kewajiban pajak yang ditanggung perusahaan membesar sehingga ada kecenderungan perusahaan melakukan praktik penghindaran pajak dengan memanfaatkan kepemilikan sumber daya yang cenderung banyak untuk mengelola beban pajaknya. Penelitian yang telah dilakukan oleh Swingly \& Sukartha (2015), Dharma \& Ardiana (2016), Dewinta \& Setiawan (2016), serta Siregar \& Widyawati (2016) menyatakan bahwa ukuran perusahaan berpengaruh positif pada penghindaran pajak. Berdasarkan uraian tersebut, maka hipotesis yang diajukan sebagai berikut.

$\mathrm{H}_{1}$ : Ukuran perusahaan berpengaruh positif pada tax avoidance.

Teori agen menyatakan bahwa good corporate governance adalah sebagai penjamin perlindungan hak-hak principal. Good Corporate Governance sebagai efektivitas mekanisme yang bertujuan meminimalkan konflik keagenan dengan penekanan khusus pada mekanisme legal. Secara konsep terdapat 5 komponen utama yang diperlukan dalam konsep GCG yaitu transparency, accountability, responsibility, independency, fairness. Kepatuhan perusahaan untuk menjalankan GCG dalam perusahaan akan menurunkan perilaku seseorang untuk melakukan praktik penghindaan pajak karena apabila sebuah perusahaan telah memahami ataupun menerapkan di perusahaan masing-masing terlebih lagi laporan keuangan akan terlihat lebih transparan, hal ini membuat para manajer kesulitan untuk melakukan praktik tax avoidance. penelitian tentang pengaruh corporate governance terhadap perilaku tax avoidance dilakukan oleh Irawan \& Farahmita (2013), Ayu \& Putri (2017), Annisa \& Lulus (2012) serta Darmadi et al., (2013). Ayu \& Putri (2017) menemukan bahwa Good Corporate Governance berpengaruh positif terhadap CETR, Irawan \& Farahmita (2013) menemukan bahwa jumlah kompensasi kepada Direktur memiliki pengaruh yang signifikan terhadap pembayaran pajak perusahaan. Mereka menemukan juga bahwa implementasi good corporate governance memiliki pengaruh positif yang signifikan terhadap pembayaran pajak perusahaan. Berdasarkan uraian tersebut, maka rumusan hipotesis yang dajukan sebagai berikut.

$\mathrm{H}_{2}$ : Good Corporate Governance memperlemah pengaruh ukuran perusahaan pada tax avoidance.

Teori trade off menyatakan bahwa penggunaan hutang perusahaan dapat digunakan untuk penghematan pajak dengan memeroleh insentif berupa beban bunga yang akan menjadi pengurang penghasilan kena pajak. Perusahaan yang lebih memilih menggunakan pendanaan eksternal seperti hutang akan mengakibatkan munculnya beban bunga yang dapat menjadi pengurang laba kena pajak. Penelitian yang dilakukan oleh Adelina (2012) menyatakan bahwa penambahan jumlah hutang akan mengakibatkan menambahnya beban bunga yang harus dibayar oleh perusahaan. Komponen beban bunga akan mengurangi laba sebelum kena pajak perusahaan, sehingga beban pajak yang harus dibayar perusahaan akan menjadi berkurang. Penelitian yang dilakukan oleh Rachmithasari (2015) menyatakan bahwa leverage berpengaruh terhadap tax avoidance. Nursari \& Sukarmanto (2017), Wijayanti \& Lely (2017), Daneshvar et al. (2017) juga menemukan hasil yang sama dimana leverage berpengaruh positif. Berdasarkan uraian tersebut, maka rumusan hipotesis yang dajukan adalah. 
$\mathrm{H}_{3}$ : Leverage memperkuat pengaruh ukuran perusahaan pada tax avoidance.

\section{METODE PENELITIAN}

Penelitian ini menggunakan metode kuantitatif yang berbentuk asosiatif. (Sugiyono 2017:20). Sumber data dalam penelitian ini adalah sumber data sekunder. Variabel yang dianalisis dalam penelitian ini diantaranya adalah variabel bebas, variabel pemoderasi, dan variabel terikat. Variabel bebas dalam penelitian ini adalah ukuran perusahaan. Variabel pemoderasi dalam penelitian ini adalah GCG dan Leverage adalah penggunaan hutang untuk membiayai investasi. Variabel terikat dalam penelitian ini adalah Tax Avoidance.

Dyreng et al. (2008) mengatakan bahwa CETR baik digunakan untuk menggambarkan kegiatan penghindaran pajak oleh perusahaan dimana tidak terpengaruh dengan adanya perubahan estimasi seperti penyisihan penilaian atau perlindungan pajak. Rumus untuk menghitung CETR sebagai berikut.

CETR $=\frac{\text { Pembayaran Pajak }}{\text { Laba sebelum pajak }}$

Jogiyanto, (2016: 259) mengatakan bahwa ukuran perusahaan dapat diukur dengan logaritma total asset, karena dinilai bahwa ukuran ini memiliki tingkat kestabilan yang lebih dibandingkan proksi-proksi yang lainnya. Dan cenderung berkesinambungan antar periode. Rumus untuk menghitung ukuran perusahaan sebagai berikut.

Ukuran perusahaan $=\log ($ total asset $)$

GCG dalam penelitian ini diukur dengan proksi Corporate for Governance Prediction Index (CGPI). Indeks yang digunakan untuk memberikan skor berupa angka mulai dari 0 sampai 100, jika perusahaan memiliki skor mendekati atau mencapai nilai 100 maka perusahaan tersebut semakin baik dalam menerapkan corporate governance. Corporate Governance Prediction Index (CGPI) merupakan program riset dan pemeringkatan penerapan tata kelola perusahaan yang baik pada perusahaan publik di Indonesia yang diselenggarakan oleh IICG, Sangat Terpercaya 85,00 - 100,00, Terpercaya 70,00 - 84,99, Cukup Terpercaya 55,00 69,99 .

Kasmir (2012: 157) mengatakan bahwa Leverage dapat diukur dengan menggunakan debt to total equity ratio (DER) karena dapat mengukur seberapa besar jumlah ekuitas perusahaan dibiayai dengan total utang. DER adalah salah satu rasio yang digunakan untuk mengukur tingkat solvabilitas perusahaan. Rumus untuk menghitung DER adalah sebagai berikut.

Debt to Total Equity Ratio $=\frac{\text { Total Hutang }}{\text { Total Ekuitas }}$

Populasi yang digunakan adalah perusahaan pertambangan dan jasa keuangan yang masuk dalam Bursa Efek Indonesia Tahun 2014-2018. Metode pengambilan sampel yang digunakan dalam penelitian ini adalah non probability sampling dengan teknik purposive sampling, yaitu teknik penentuan sampel dengan pertimbangan tertentu sehingga sampel yang dibentuk dapat mewakili sifat-sifat populasi (Sugiyono, 2013: 112). Beberapa kriteria yang digunakan adalah Perusahaan pertambangan dan jasa keuangan yang terdaftar di BEI selama tahun periode 2014-2018, Perusahaan pertambangan dan jasa keuangan dengan nilai laba setelah pajak yang positif untuk tahun 2014-2018. Perusahaan yang 
mengalami kerugian tidak memiliki kewajiban membayar pajak sehingga mengakibatkan effective tax rate menjadi negatif terdistorsi. Richardson et al. (2015) Perusahaan pertambangan dan jasa keuangan dengan nilai CETR kurang dari satu agar tidak menimbulkan masalah dengan estimasi model (Gupta \& Newberry, 1997), Perusahaan pertambangan dan jasa keuangan yang masuk dalam pemeringkatan CGPI sebagai most trusted company berturut-turut dari tahun 20142018 yang dilakukan oleh IICG dan dipublikasikan oleh majalah SWA.

\section{HASIL DAN PEMBAHASAN}

Berikut pada Tabel 5, yang memperlihatkan secara rinci proses seleksi pemilihan sampel penelitian.

\section{Tabel 5. Seleksi Pemilihan Sampel}

\begin{tabular}{llc}
\hline No & \multicolumn{1}{c}{ Kriteria } & Jumlah Perusahaan \\
\hline 1 & $\begin{array}{l}\text { Perusahaan pertambangan dan jasa keuangan yang } \\
\text { terdaftar di BEI periode tahun 2014-2018 }\end{array}$ & 93 \\
2 & $\begin{array}{l}\text { Perusahaan pertambangan dan jasa keuangan yang } \\
\text { tidak masuk dalam pemeringkatan CGPI berturut- }\end{array}$ & $(83)$ \\
$\quad \begin{array}{l}\text { turut dari tahun 2014-2018 } \\
3\end{array}$ & $\begin{array}{l}\text { Perusahaan yang memiliki data pajak tidak } \\
\text { lengkap }\end{array}$ & $(1)$ \\
& $\begin{array}{l}\text { Perusahaan pertambangan dan jasa keuangan yang } \\
\text { mengalami kerugian selama tahun 2014-2018 }\end{array}$ & $(1)$ \\
& Jumlah Sampel & 8 \\
& Tahun Observasi & 5 \\
& Jumlah Observasi 2014-2018 & 40 \\
\hline
\end{tabular}

Sumber: www.idx.co.id., 2019

Berdasarkan Tabel 5, kriteria sampel telah ditentukan, sehingga diperoleh sampel yang digunakan dalam penelitian ini berjumlah 8 perusahaan yang diamati selama 5 tahun sehingga diperoleh 40 perusahaan pengamatan. Hasil dari pengujian statistik deskriptif penelitian dapat dilihat pada Tabel 6.

Tabel 6. Hasil Analisis Statistik Deskriptif

\begin{tabular}{lrrrrr}
\hline & N & \multicolumn{1}{c}{ Minimum } & Maximum & \multicolumn{1}{c}{ Mean } & Std. Deviation \\
\hline SIZE & 40 & 7.15 & 10.52 & 8.718 & 0.864 \\
GCG & 40 & 85.25 & 93.86 & 88.314 & 2.359 \\
LVRG & 40 & 0.49 & 11.40 & 5.105 & 3.087 \\
CETR & 40 & 0.01 & 0.610 & 0.256 & 0.106 \\
Valid N (listwise) & 40 & & & & \\
\hline
\end{tabular}

Sumber: Data Penelitian, 2020

Tabel 6, menunjukkan hasil analisis statistik deskriptif masing-masing variabel. Ukuran perusahaan menunjukkan nilai minimum sebesar 7,15, nilai maksimum sebesar 10,52 nilai rata-rata (mean) sebesar 8,718 dan standar deviasi sebesar 0,864. GCG memiliki nilai minimum sebesar 85,25 nilai maksimum sebesar 93,860, nilai rata-rata (mean) sebesar 88,314 dan standar deviasi sebesar 2,359. Leverage memiliki nilai minimum sebesar 0,49 nilai maksimum sebesar 11,40 nilai rata-rata (mean) sebesar 5,105 dan standar deviasi sebesar 3.087. Tax Avoidance memiliki nilai minimum sebesar 0,01 , nilai maksimum sebesar 0,61 , nilai rata-rata (mean) sebesar 0,256, dan dtandar deviasi sebesar 0,106. 
Tabel 7. Hasil Moderated Regression Analysis

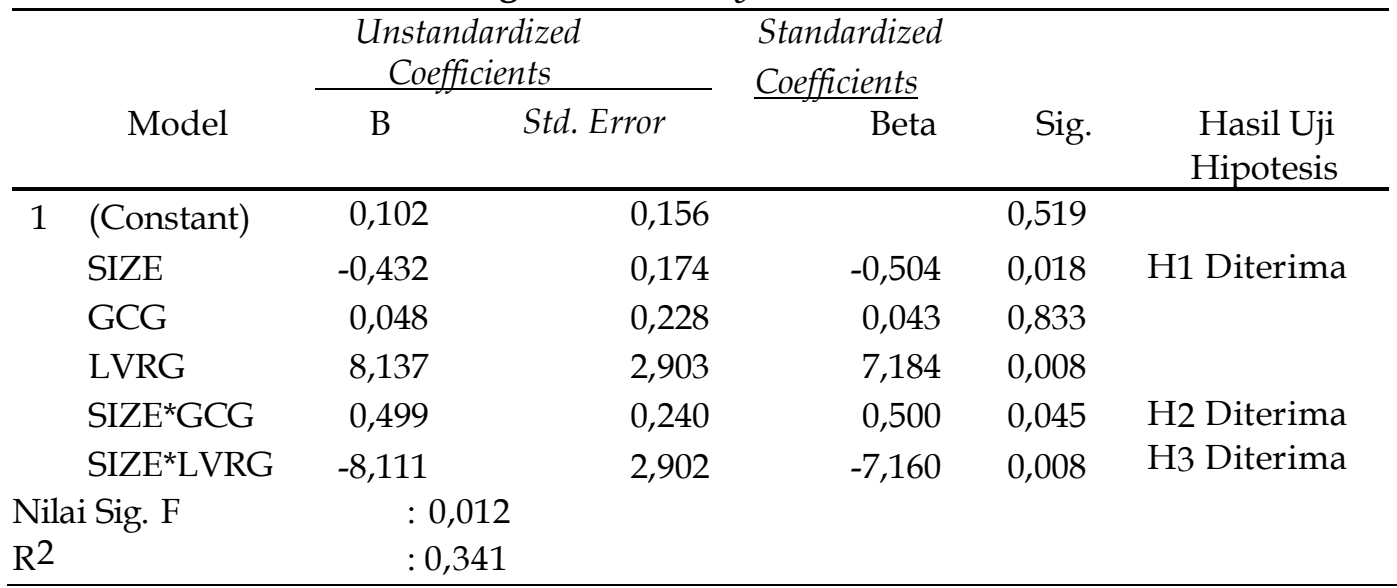

Sumber: Data Penelitian, 2020

Tabel 7, menunjukkan bahwa nilai sig $\mathrm{F}$ yang diperoleh adalah sebesar 0,012. Signifikansi ini jelas lebih kecil dari Alpha $(a=0,05)$ maka model regresi telah memenuhi prasyarat ketepatan fungsi regresi. Jadi, model regresi moderasi ini sudah tepat digunakan untuk memprediksi pengaruh variabel GCG dan Leverage terhadap pengaruh ukuran perusahaan pada tax avoidance.

Koefisien determinasi yang digunakan dalam penelitian ini yakni $R^{2}$ yang diperoleh sebesar 0,341 . Ini berarti perubahan yang terjadi pada tax avoidance dapat dipengaruhi secara signifikan oleh variabel ukuran perusahaan $(X 1)$, leverage $(X 2)$, GCG (X3), variabel interaksi antara ukuran perusahaan dengan leverage (M1), variabel interaksi antara ukuran perusahaan dengan GCG (M2) sebesar 34,1 persen, sedangkan 65,9 persen sisanya dijelaskan oleh faktor lain yang tidak diuji dalam penelitian ini. Uji ini dilakukan untuk mengetahui pengaruh variabel moderasi secara individual pada variabel terikat. Hasil uji menunjukkan pengaruh ukuran perusahaan pada tax avoidance dimana diperoleh hasil bahwa nilai thitung sebesar sebesar $-2,487$ dengan tingkat signifikansi t sebesar 0,018 yang lebih kecil dari 0,05 (Sig < a). Hal ini menunjukkan bahwa ukuran perusahaan berpengaruh negatif pada CETRatau berpengaruh positif pada tax avoidance, sehingga H1 diterima. Hubungan positif ini mendukung teori biaya politik dimana semakin besar biaya politik perusahaan, maka semakin mungkin manajer perusahan untuk memilih metode akuntansi yang menangguhkan laba periode sekarang ke periode mendatang. Semakin tinggi ukuran perusahaan yang diwakili dari nilai Ln total asset maka semakin rendah nilai CETR. Nilai ETR yang rendah menunjukkan semakin agresif tindakan penghindaran pajak yang dilakukan perusahaan. Semakin besar ukuran perusahaannya, maka transaksi yang dilakukan akan semakin kompleks. Hal ini memungkinkan perusahaan untuk memanfaatkan celah-celah yang ada untuk melakukan tindakan penghindaran pajak dari setiap transaksi.

Hasil yang diperoleh dalam penelitian ini sejalan dengan penelitian sebelumnya, oleh Darmawan \& Sukartha (2014), Swingly \& Sukartha (2015) yang menyatakan bahwa ukuran perusahaan berpengaruh negatif dan signifikan terhadap CETR. Penelitian ini juga sejalan dengan hasil penelitian Higgins et al, (2015) yang mengungkapkan bahwa ukuran perusahaan yang diwakili oleh nilaiaset memiliki pengaruh positif yang signifikan terhadap penghindaran pajak, maka penelitian ini pun berhasil membuktikan bahwa ukuran perusahaan 
memiliki pengaruh signifikan negatif terhadap CETR. Sedangkan ETR berbanding terbalik dengan tingkat penghindaran pajak. Semakin besar ukuran perusahaan yang diwakili oleh nilai aset, maka semakin besar kecenderungan perusahaan tersebut untuk melakukan penghindaran pajak secara agresif.

Hasil uji moderasi pada Tabel 7, menunjukkan interaksi antara GCG dan ukuran perusahaan pada Tax Avoidance diperoleh nilai t hitung sebesar 2.082 dengan signifikansi sebesar 0,045 lebih kecil dari 0,05. Hal ini berarti GCG dapat memoderasi Ukuran Perusahaan pada Tax Avoidance. Hubungan positif ini menyebabkan adanya interaksi antara ukuran perusahaan dengan GCG yang dapat meningkatkan tingkat presentase CETR atau sama dengan menurunkan tingkat tax avoidance yang dilakukan perusahaan dimana menandakan bahwa GCG mampu memperlemah pengaruh ukuran perusahaan pada tax avoidance. Hubungan negatif yang menyebabkan adanya interaksi memperlemah variabel ukuran perusahaan pada tax avoidance oleh variabel GCG, karena sesuai dengan teori agensi, good corporate governance yang diterapkan oleh perusahaan dapat menurunkan monitoring cost dengan cara melakukan praktik peningkatan pengawasan, pengamatan, dan transparasi. Penerapan GCG dalam perusahaan yang tertata dan tersistem dengan baik tentunya dapat membuat agen bekerja sesuai dengan tujuan tanpa adanya sikap yang menyeleweng terhadap kewajiban pembayaran pajak. Hal ini akan menurunkan kemungkinan munculnya masalah keagenan yang merugikan dan dapat menjaga kelangsungan perusahaan.

Hasil penelitian ini sejalan dengan penelitian yang telah dilakukan oleh Irawan \& Farahmita (2013), Ayu \& Putri (2017), Annisa \& Lulus (2012) serta Darmadi et al. (2013) yang menyatakan bahwa GCG mempunyai pengaruh positif terhadap CETR atau pembayaran pajak.

Hasil uji moderasi pada Tabel 7, menunjukkan interaksi antara Leverage dengan ukuran perusahaan pada Tax Avoidance. Diperoleh nilai $\mathrm{t}$ hitung sebesar -2.795 dengan signifikansi sebesar 0,008 lebih kecil dari 0,05. Hal ini berarti Leverage dapat memoderasi Ukuran Perusahaan pada Tax Avoidance. Hal ini menunjukkan bahwa interaksi antara ukuran perusahaan dengan leverage dapat menurunkan tingkat presentase CETR atau sama dengan meningkatkan tingkat presentase tax avoidance yang dilakukan perusahaan dimana menandakan bahwa leverage mampu memperkuat pengaruh ukuran perusahaan pada tax avoidance.

Hubungan negatif yang menyebabkan adanya interaksi memperkuat antara variabel leverage dengan ukuran perusahaan ini terjadi didukung oleh Trade-Off Theory dimana semakin tinggi nilai dari rasio leverage berarti semakin tinggi jumlah pendanaan dari utang pihak ketiga yang digunakan perusahaan dan semakin tinggi pula biaya bunga yang timbul. Dengan adanya biaya bunga yang semakin tinggi akan memberikan pengaruh berkurangnya laba sebelum pajak perusahaan, maka hal tersebut memberikan pengaruh terhadap beban pajak perusahaan yang semakin rendah.

Hasil penelitian ini mendukung penelitian dari Nursari \& Sukarmanto (2017), Wijayanti \& Lely (2017), Daneshvar et al. (2017) yang menemukan hasil bahwa leverage berpengaruh positif pada tax avoidance.

\section{SIMPULAN}

Berdasarkan pada hasil analisis dan pembahasan pada hasil penelitian ini dapat ditarik beberapa kesimpulan yakni ukuran perusahaan berpengaruh positif pada 
tax avoidance. Hal ini menunjukkan bahwa semakin besar ukuran perusahaan maka tingkat praktik tax avoidance perusahaan tersebut semakin tinggi. Interaksi antara ukuran perusahaan dengan GCG dapat menyebabkan nilai CETR meningkat atau menurunkan praktik tax avoidance. Dalam penelitian ini GCG dapat memperlemah pengaruh ukuran perusahaan pada tax avoidance. Hal ini menunjukkan bahwa apabila perusahaan menerapkan GCG dalam sistem perusahaannya maka praktik penghindaran pajak dapat diminimalisir. Interaksi anatara ukuran perusahaan dengan leverage dapat menyebabkan nilai CETR menurun atau menaikkan tingkat praktik tax avoidance. Dalam penelitian ini leverage dapat memperkuat pengaruh ukuran perusahaan pada tax voidance. Hal ini menunjukkan bahwa semakin tingginya leverage dalam perusahaan maka semakin tinggi pula tingkat penghindaran pajaknya.

Hasil penelitian menunjukkan bahwa ukuran perusahaan berpengaruh positif pada tax avoidance, sehingga pemerintah dapat lebih ketat melakukan pengawasan terkait pelaporan perpajakan khususnya untuk perusahaan yang berukuran besar.

Penelitian selanjtnya diharapkan dapat menggunakan sektor perusahaan yang lebih banyak populasinya dalam hal ini seluruh sektor yang terdaftar pada Bursa Efek Indonesia. Penelitian selanjutnya diharapkan dapat menggunakan teori-teori lainnya untuk mendukung penelitian tentang Tax Avoidance.

\section{REFERENSI}

Adelina, T. (2012). Pengaruh Karakteristik Perusahaan dan Reformasi Perpajakan Terhadap Penghindaran Pajak di Perusahaan Industri Manufaktur yang terdaftar di Bursa Efek Indonesia Tahun 2008-2010.

Armstrong, C. S., Blouin, J. L., Jagolinzer, A. D., \& Larcker, D. F. (2015). Corporate governance, incentives, and tax avoidance. Journal of Accounting and Economics. https://doi.org/10.1016/j.jacceco.2015.02.003

Brigham, \& Weston, J. . (1998). Manajemen Keuangan (8th ed.). https:/ / doi.org/10.1016/0377-841X(78)90069-4

Budiman, J., \& Setiyono. (2012). Pengaruh Karakter Eksekutif Terhadap Penghindaran Pajak (Tax Avoidance). Jurnal Universitas Islam Sultan Agung., $1(4), 53$.

Cahyono, D. D., Andini, R., \& Raharjo, K. (2016). Pengaruh Komite Audit, Kepemilikan Institusional, Dewan Komisaris, Ukuran Perusahaan (Size), Leverage (DER) Dan Profitabilitas (ROA) Terhadap Tindakan Penghindaran Pajak (Tax Avoidance) Pada Perusahaan Perbankan Yang Listing Bei Periode Tahun 2011 2013. 2(2).

Daneshvar, M. E., Aghdaei, S. H., Baseri, M., \& Hassanpour, D. (2017). Investigating the effective factors on role of Internal Auditing in Accepted Corporations in Tehran Stock Exchange. 5(3), 304-309. https:// doi.org/10.17354/ijssJuneI/2017/45

Dewinta, I. A. R., \& Setiawan, P. E. (2016). Pengaruh Ukuran Perusahaan, Umur Perusahaan, Profitabilitas, Leverage, dan Pertumbuhan Penjualan terhadap Tax Avoidance. E-Jurnal Akuntansi, 14, 1584-1615. Retrieved from https://ojs.unud.ac.id/index.php/Akuntansi/article/view/16009

E Janrosl, V. S. (2019). Analisis Good Corporate Governance Dan Ukuran Perusahaan Terhadap Tax Avoidance Pada Pt Bank Riau Kepri. Jurnal Pundi, 3(1), 71-78. https://doi.org/10.31575/jp.v2i3.107 
Ghozali, I. (2012). Aplikasi Analisis Multivariat dengan Program IBM SPSS 20 (Edisi keenam). Semarang: Universitas Diponegoro. Metode Penelitian Bisnis.

Govindarajan, V. (1986). Impact of participation in the budgetary process on managerial attitudes and performance: universalistic and contingency perspectives. Decision Sciences. https://doi.org/10.1111/j.15405915.1986.tb00240.x

Harjito, A., \& Martono. (2010). Manajemen Keuangan. Yogyakarta: Ekonisia.

Hendriksen, E. S., \& Breda, M. F. V. (1992). Accounting Theory. Fifth Edition. USA:

Indriantoro, N., \& Supomo, B. (2013). Metodologi Penelitian Bisnis Untuk Akuntansi $\mathcal{E}$ Manajemen (1st ed.). Yogyakarta: BPFE.

Irawan, H. P., \& Farahmita, A. (2013). The Effect of ManagementCompensation and Corporate Governance on Corporate Tax Management. The Indonesian Journal of Accounting Research, 16(1), 1-17. https:// doi.org/10.1017/CBO9781107415324.004

Jensen, M. C., \& Meckling, W. H. (1976). Theory Of The Firm: Managerial Behavior, Agency Costs and Ownership Structure Michael C. Jensen and William H. MecklingT. Journal of Financial Economics.

Jogiyanto. (2016). Teori Portofolio dan Analisis Investasi (Edisi Sepuluh). Yogyakarta: BPFE.

Kasmir. (2012). Analisis Laporan Keuangan. Jakarta: Rajawali Press. Edisi 8.

Kurniasih, T., \& Sari, M. M. R. (2013). Pengaruh Return on Assets, Leverage, Corporate Governance, Ukuran Perusahaan Dan Kompensasi Rugi Fiskal Pada Tax Avoidance. Buletin Studi Ekonomi, 18(1), 58-66.

Marfu'ah, L. (2015). Pengaruh Return on Asset, Leverage, Ukuran Perusahaan, Kompensasi Rugi Fiskal dan Koneksi Politik Terhadap Tax Avoidance. Simposium Nasional Akuntansi XVIII. https:// doi.org/10.1109/CAC.2015.7382785

Murray, D. (1990). The performance effects of participative budgeting: An integration of intervening and moderating. Behavioral Research in Accounting.

Nugrahitha, I. M. A., \& Suprasto, H. B. (2018). Pengaruh Profitabilitas, Leverage, Corporate Governance, dan Karakter Eksekutif pada Tax Avoidance. E-Jurnal Akuntansi, 22(36), 2016-2039. https:/ / doi.org/10.24843/EJA.2018.v22.i03.p14

Palupi, I. S. (2018). Pengaruh Ukuran Perusahaan, Sales Growth dan Leverage Terhadap Tax Avoidance, dengan Profitabilitas sebagai Variabel Moderating (Studi Empiris pada Perusahaan Manufaktur Terdaftar di Bursa Efek Indonesia Tahun 2014-2016). Jurnal Fakultas Ekonomi Dan Bisnis, Universitas Muhammadiyah Siurakarta, 10(2), 1-15.

Rachmithasari, annisa fadilla. (2015). Pengaruh Return On Assets, Leverage, Corporate Governance, Ukuran Perusahaan dan Kompensasi Rugi Fiskal pada Tax Avoidance (Perusahaan Manufaktur yang Terdaftar di Bursa Efek Indonesia Tahun 2011-2013). Jurnal Fakultas Ekonomi Dan Bisnis, Universitas Muhammadiyah Siurakarta.

Riset, M. (2009). An Examination of Corporate Tax Shelter Participants The University of Iowa. https:// doi.org/10.2308/accr.2009.84.3.969

Sugiyono. (2013). Metode Penelitian Pendidikan Pendekatan Kuantitaif, Kualitatif, dan R\&D. Bandung CV alfabeta. Metode Penelitian Pendidikan Pendekatan Kuantitaif, Kualitatif, Dan RED. https:/ / doi.org/10.1007/s13398-014-0173-7.2 
Tandean, V. A. (2016). Good Corporate Governance Dan Ukuran Perusahaan Pengaruhnya Pada Tax Avoidance. Jurnal Ilmiah Akuntansi Dan Bisnis, 978979. https://doi.org/10.24843/jiab.2016.v11.i01.p07

Waluyo. (2012). Perekonomian Indonesia (Edisi 12). Jakarta: Salemba Empat.

Yogiswari, N. K. K., \& Ramantha, I. W. (2017). Pengaruh Likuiditas Dan Corporate Social Responsibility Pada Agresivitas Pajak Dengan Corporate Governace Sebagai Variabel Pemoderasi. E-Journal Akuntansi Universitas Udayana, 21(1), 730-759.

Yulfaida, D., \& Zhulaikha. (2012). Pengaruh Size , Profitabilitas , Profile , Leverage Dan Ukuran Dewan Komisaris Terhadap Perusahaan Manufaktur. Diponegoro Journal of Accounting, 1(1), 1-11. 